\title{
REPRODUKSI IKAN BAUNG (Hemibagrus nemurus) DENGAN PERLAKUAN DOSIS HORMON GnRH-a BERBEDA
}

\author{
Jojo Subagja dan Vitas Atmadi Prakoso" \\ Balai Riset Perikanan Budidaya Air Tawar dan Penyuluhan Perikanan \\ Jl. Sempur No. 1, Bogor 16129
}

(Naskah diterima: 19 Maret 2018; Revisi final: 10 Juli 2018; Disetujui publikasi: 10 Juli 2018)

\begin{abstract}
ABSTRAK
Ikan baung (Hemibagrus nemurus) memiliki prospek bagus untuk dikembangkan sebagai komoditas budidaya di Indonesia karena citarasa daging yang enak banyak diminati konsumen. Dewasa ini, peningkatan produksi benih dapat dilakukan melalui pemijahan buatan dengan manipulasi hormonal. Penelitian yang dilakukan bertujuan untuk mengevaluasi produksi induk ikan baung melalui pemijahan buatan dengan dosis penyuntikan GnRH-a berbeda. Penelitian dilakukan di Instalasi Riset Plasma Nutfah Perikanan Air Tawar, Cijeruk, Bogor pada bulan November 2017. Induk betina ikan baung yang digunakan berukuran 465,0 \pm $71,8 \mathrm{~g}$; dan induk jantan $426,3 \pm 46,8 \mathrm{~g}$. Induksi dilakukan dengan penyuntikan hormon $\mathrm{GnRH}$-a dengan tiga dosis yang berbeda pada induk betina $(0,3 ; 0,5 ;$ dan $0,7 \mathrm{~mL} / \mathrm{kg}$ bobot badan), dan ikan jantan dengan dosis $0,4 \mathrm{~mL} / \mathrm{kg}$ bobot badan. Masing-masing perlakuan terdiri atas tiga ekor induk betina sebagai ulangan. Hormon disuntikkan secara intramuskular, diberikan dua kali penyuntikan 35\% dari dosis total pada penyuntikan pertama, dan $65 \%$ diberikan pada penyuntikan kedua, dengan interval waktu penyuntikan delapan jam. Parameter yang diamati yaitu jumlah telur ovulasi, derajat pembuahan, derajat penetasan, dan sintasan larva selama tujuh hari. Hasil penelitian menunjukkan bahwa dosis penyuntikan hormon GnRH-a 0,5 mL/kg pada induk ikan baung saat proses pemijahan buatan menghasilkan derajat penetasan yang lebih tinggi dibandingkan dosis 0,3 dan $0,7 \mathrm{~mL} / \mathrm{kg}$; serta sintasan larva yang lebih baik dibandingkan dosis $0,7 \mathrm{~mL} / \mathrm{kg}$. Sedangkan nilai jumlah telur yang berhasil ovulasi dan derajat pembuahan yang relatif lebih baik ditemukan pada perlakuan dosis $0,7 \mathrm{~mL} / \mathrm{kg}$ dibandingkan dengan dosis 0,3 dan $0,5 \mathrm{~mL} / \mathrm{kg}$.
\end{abstract}

\section{KATA KUNCl: Hemibagrus; baung; reproduksi; hormon}

ABSTRACT: Reproduction of Asian redtail catfish (Hemibagrus nemurus) using different doses of GnRH-a hormone. By: Jojo Subagja and Vitas Atmadi Prakoso

Asian redtail catfish (Hemibagrus nemurus) has a good prospect to be developed as aquaculture commodity in Indonesia. It was proved by the demand of consumers regarding to its delicious flesh taste. Recently, efforts to increase seedling production could be implemented through artificial spawning with hormonal manipulation. This study was conducted to evaluate the production of broodstocks through artificial spawning with different doses of GnRH-a. Study was conducted at Research Institute for Freshwater Fisheries Germplasm, Cijeruk, Bogor in November, 2017. The broodstock used in this study was $465.0 \pm 71.8 \mathrm{~g}$ for females, and $426.3 \pm 46.8 \mathrm{~g}$ for males. Induction was performed by injection of $\mathrm{GnRH}$-a hormone with three different doses on female broodstocks $(0.3,0.5$ and $0.7 \mathrm{~mL} / \mathrm{kg}$ of body weight), and male broodstocks with a dose of $0.4 \mathrm{~mL} / \mathrm{kg}$ of body weight. Each treatment consisted of three females as replications. The hormone was injected intramuscularly, given twice injection: $35 \% 0$ thetotal dose is given at the first injection, and the remaining $65 \%$ was given at the second injection, with an injection time interval of eight hours. The results showed the observed parameters of number of the ovulated eggs, fertilization rate, hatching rate, and larval survival for seven days, treatment dosage of $0.5 \mathrm{~mL} / \mathrm{kg}$ showed better results $(P<0.05)$ than the dosage of $0.3 \mathrm{~mL} / \mathrm{kg}$ and $0.7 \mathrm{~mL} / \mathrm{kg}$. Parameters observed were number of ovulated eggs, fertility rate, hatching rate, and survival rate for seven days. The results showed that the dosage of $0.5 \mathrm{~mL} / \mathrm{kg} \mathrm{GnRH}-\mathrm{a}$ injection to the broodstock during artificial spawning resulted in higher hatching rate compared to 0.3 and $0.7 \mathrm{~mL} / \mathrm{kg}$ and better larval survival rate than

\footnotetext{
\# Korespondensi: Balai Riset Perikanan Budidaya Air Tawar dan

Penyuluhan Perikanan.

Jl. Sempur No. 1, Bogor 16129, Indonesia.

Tel. + 622518313200

E-mail: vitas.atmadi@gmail.com
} 
Reproduksi ikan baung (Hemibagrus nemurus) dengan perlakuan ..... (Jojo Subagja)

the dosage of $0.7 \mathrm{~mL} / \mathrm{kg}$. Meanwhile, the number of ovulated eggs and fertility rate was relatively better in the treatment of $0.7 \mathrm{~mL} / \mathrm{kg}$ compared with the dosage of 0.3 and $0.5 \mathrm{~mL} / \mathrm{kg}$.

\section{KEYWORDS: Hemibagrus; Asian redtail catfish; reproduction; hormone}

\section{PENDAHULUAN}

Ikan baung merupakan salah satu ikan konsumsi yang penting di Indonesia. Tekstur dagingnya yang lembut dan tebal berwarna putih tanpa duri halus membuat ikan ini banyak digemari masyarakat, khususnya di wilayah Sumatera, seperti di Jambi (Nasution et al., 1993) dan Riau (Sukendi, 2001). Di Jawa Barat, jenis ikan ini digemari masyarakat dan mempunyai harga lebih tinggi daripada harga ikan mas. Ikan ini memiliki kisaran harga Rp50.000,00Rp100.000,00/kg (Irwanda, 2018; Kesuma, 2018).

Komersialisasi dan budidaya intensif terhadap spesies ini masih terbatas, karena ketidakmampuan untuk berkembang biak secara alamiah di tempat penangkaran, penyediaan benih untuk pembesaran sebagian besar masih mengandalkan tangkapan dari alam (Subagja et al., 2015). Pengembangbiakan ikan baung secara buatan mulai dikerjakan sejak tahun 1992, proses pemijahan menggunakan induksi hormon alami yang diambil dari ekstrak kelenjar hipofisa ikan mas sebagai ikan donor universal (Gaffar \& Muflikah, 1992). Pemijahan secara buatan melalui induksi hormon gonadotropin komersial juga telah dilakukan oleh Hardjamulia \& Suhenda (2000).

Beberapa penelitian terdahulu terkait dengan dosis hormon reproduksi yang disuntikkan pada ikan telah dilakukan, di antaranya pada ikan patin Pangasius hypopthalmus (Legendre et al., 2000), ikan lele Clarias gariepinus (Sahoo et al., 2007; Achionye-Nzeh \& Obaroh, 2012; Olumuji \& Mustapha, 2012), dan ikan selais Ompok rhadinurus (Nuraini et al., 2013). Pada umumnya hormon reproduksi yang dipergunakan adalah gonadotropin (GnRH) baik yang alami ataupun yang sintetik, seperti yang dinyatakan Lam (1995) bahwa GnRH berperan merangsang hipofisis untuk melepaskan gonadotropin.

Informasi mengenai perbedaan dosis hormon yang disuntikkan saat pemijahan buatan terhadap keragaan bioreproduksi dan kualitas larva pada ikan baung ini belum banyak dipelajari dan dikaji lebih dalam. Oleh karena itu, penelitian ini dilakukan untuk mengamati keragaan reproduksi dan sintasan larva ikan baung hasil pemijahan buatan dengan dosis penyuntikan hormon yang berbeda.

\section{BAHAN DAN METODE}

Penelitian dilakukan di Instalasi Riset Plasma Nutfah Perikanan Air Tawar, Cijeruk, Bogor pada bulan November 2017. Induk ikan baung dipelihara di kolam beton berukuran $8 \mathrm{~m} \times 10 \mathrm{~m}$, dengan kedalaman air kolam $1 \mathrm{~m}$. Ikan secara teratur diberi makan berupa pakan komersial (kadar protein 30\%protein) sebanyak $2 \%$ dari bobot badan. Ikan baung yang digunakan merupakan populasi Cirata generasi kedua hasil domestikasi (Subagja et al., 2015). Pemilihan induk betina untuk pemijahan ditentukan berdasarkan tingkat kematangan gonad yang sudah mencapai matang akhir (TKG IV), di mana diameter telur sudah mencapai kisaran 1,4-1,6 mm; bobot rataan induk betina yang dipergunakan adalah 465,0 $\pm 71,8 \mathrm{~g}$. Induk jantan dipilih berdasarkan kriteria panjang papilla genitalia, ikan yang dipergunakan bila panjang papilla sudah melewati pangkal sirip anal, dan ujung papilla genitalia berwarna kemerahan (Subagja et al., 2015). Bobot induk jantan yang digunakan mencapai rataan 426,3 $\pm 46,8 \mathrm{~g}$.

Penimbangan bobot masing-masing induk betina dilakukan sebelum menyuntikkan hormon. Induksi dilakukan dengan penyuntikan hormon GnRH-a (Ovaprim ${ }^{\circledR}$ 'Syndel Laboratories', Canada) dengan tiga dosis yang berbeda pada induk betina $(0,3 ; 0,5$; dan $0,7 \mathrm{~mL} / \mathrm{kg}$ bobot badan). Sementara itu, dosis tunggal digunakan untuk penyuntikan induk jantan, yaitu 0,4 $\mathrm{mL} / \mathrm{kg}$ bobot badan (Slembrouck et al., 2005). Hormon disuntikkan secara intramuskular. Induk jantan disuntik satu kali yang dilakukan pada saat suntikan pertama pada ikan betina, sedangkan induk betina disuntik dua kali (penyuntikan pertama sebesar 35\% dan penyuntikan kedua sebesar $65 \%$ dari total dosis) dengan interval waktu penyuntikan delapan jam (Legendre et al., 2000). Masing-masing perlakuan terdiri atas tiga ekor induk betina sebagai ulangan.

Telur dari betina dikeluarkan dengan cara diurut di bagian perutnya dan segera dibuahi dengan sperma. Induk jantan dibedah, diambil testisnya, kemudian digunting menjadi beberapa bagian berukuran kecil. Sperma yang diperoleh dicampurkan dengan $\mathrm{NaCl}$ fisiologis dalam wadah dengan perbandingan campuran $1 \mathrm{~mL}$ sperma ditambahkan $4 \mathrm{~mL} \mathrm{NaCl}$, sperma dari ketiga induk jantan digabungkan untuk membuahi telur.

Aktivasi spermatozoa diperoleh dengan penambahan $10 \mathrm{~mL}$ air yang kemudian diaduk selama satu menit dengan lembut. Penghitungan jumlah telur diovulasikan oleh induk ikan baung betina pada masing-masing perlakuan juga dilakukan dengan menimbang sampel telur sebanyak $1 \mathrm{~g}$ telur dari masing-masing induk. Telur dari masing-masing 
perlakuan dosis kemudian dibilas dengan air bersih dan ditetaskan pada wadah plastik berukuran $10 \mathrm{~cm} x$ $5 \mathrm{~cm} \times 5 \mathrm{~cm}$ (volume air: $750 \mathrm{~mL}$ ) sebanyak 825 butir/ wadah (masing-masing ulangan dihitung secara manual) dengan tiga ulangan untuk pengamatan derajat pembuahan dan derajat penetasan telur.

Larva menetas dari masing-masing ulangan perlakuan dihitung berdasarkan jumlah awal telur yang digunakan untuk menentukan derajat penetasan telur pada masing-masing perlakuan dosis penyuntikan. Kemudian larva yang menetas dari masing-masing perlakuan diamati sintasannya di akuarium berukuran $40 \mathrm{~cm} \times 40 \mathrm{~cm} \times 30 \mathrm{~cm}$ selama tujuh hari masa pemeliharaan dengan pemberian pakan berupa Artemia dan Tubifex. Data dianalisis secara statistik dengan menggunakan one-way ANOVA dan uji-T menggunakan bantuan program SPSS versi 18, dengan selang kepercayaan $95 \%$ Pengaruh perlakuan dianggap signifikan apabila $\mathrm{P}<0,05$.

\section{HASIL DAN BAHASAN}

Jumlah telur yang berhasil ovulasi dan derajat penetasan telur ikan baung yang diinduksi dengan GnRH-a pada beberapa dosis yang berbeda disajikan pada Tabel 1. Hasil penelitian ini menunjukkan bahwa jumlah telur yang berhasil ovulasi pada perlakuan dosis 0,5 dan $0,7 \mathrm{~mL} / \mathrm{kg}$ lebih tinggi dibandingkan perlakuan dosis $0,3 \mathrm{~mL} / \mathrm{kg}(\mathrm{P}<0,05)$. Tidak terdapat perbedaan nyata pada jumlah telur dan derajat pembuahan antara perlakuan dosis $0,5 \mathrm{~mL} / \mathrm{kg}$ dengan $0,7 \mathrm{~mL} / \mathrm{kg}(P>0,05)$. Namun, nilai yang dihasilkan pada dosis $0,7 \mathrm{~mL} / \mathrm{kg}$ relatif lebih baik dibandingkan $0,5 \mathrm{~mL} / \mathrm{kg}$. Kedua perlakuan tersebut memiliki nilai yang lebih baik dibandingkan perlakuan $0,3 \mathrm{~mL} / \mathrm{kg}$ yang mengalami kematian total $(P<0,05)$. Pada parameter derajat penetasan, persentase tertinggi diperoleh pada perlakuan $0,5 \mathrm{~mL} / \mathrm{kg}(\mathrm{P}<0,05)$; diikuti oleh perlakuan $0,7 \mathrm{~mL} / \mathrm{kg}$; dan terendah adalah $0,3 \mathrm{~mL} / \mathrm{kg}$ (Tabel 1).
Menurut DiMaggio et al. (2013), pengaruh dosis dari induksi hormon saat pemijahan terhadap keragaan reproduksi pada ikan merupakan hal yang harus dipertimbangkan. Hal tersebut berhubungan dengan frekuensi pemijahan dari spesies ikan tersebut dan juga kualitas telur. Jika dikaitkan dengan hasil penelitian ini, dosis terbaik GnRH-a untuk parameter derajat penetasan telur ikan baung adalah $0,5 \mathrm{~mL} / \mathrm{kg}$. Namun, untuk parameter derajat pembuahan dan jumlah telur yang berhasil ovulasi, dosis $0,7 \mathrm{~mL} / \mathrm{kg}$ relatif lebih baik dibandingkan dosis $0,5 \mathrm{~mL} / \mathrm{kg}$. Sedangkan simpangan baku yang besar ditemukan pada derajat penetasan dari dosis $0,7 \mathrm{~mL} / \mathrm{kg}$. Pada dosis tersebut, dapat diprediksi bahwa kualitas telur pada parameter derajat pembuahan dan derajat penetasan yang dihasilkan pada dosis $0,5 \mathrm{~mL} / \mathrm{kg}$ lebih baik dibandingkan dengan dosis $0,3 \mathrm{~mL} / \mathrm{kg}$; namun tidak lebih baik dibandingkan dengan $0,7 \mathrm{~mL} / \mathrm{kg}$. Bromage et al. (1992) menyatakan bahwa telur yang berkualitas memiliki mortalitas rendah pada saat pembuahan dan penetasan, sehingga dihasilkan larva yang berkualitas dan tahan terhadap kondisi lingkungan. Akan tetapi, tidak demikian pada hasil penelitian ini. Dosis 0,7 $\mathrm{mL} / \mathrm{kg}$ relatif lebih baik daripada $0,5 \mathrm{~mL} / \mathrm{kg}$; kecuali untuk parameter derajat penetasan. Derajat penetasan yang lebih rendah pada dosis $0,7 \mathrm{~mL} / \mathrm{kg}$ diakibatkan oleh kematian ekstrem yang dicirikan oleh simpangan baku yang besar.

Hasil dari penelitian ini juga menunjukkan bahwa peningkatan dosis penyuntikan hormon dapat berdampak negatif terhadap penurunan derajat pembuahan dan penetasan (Mylonas et al., 1992; DiMaggio et al., 2013). Hasil ini juga serupa dengan hasil penelitian Adebiyi et al. (2013) yang menggunakan GnRH-a mamalia dan ovaprim untuk induksi pemijahan ikan baung. Pengaruh dari perbedaan dosis penyuntikan hormon terhadap kualitas dan kuantitas telur ini juga telah dilaporkan pada beberapa penelitian

Tabel 1. Jumlah telur yang berhasil ovulasi dan derajat penetasan telur ikan baung (Hemibagrus nemurus) dengan perlakuan perbedaan dosis hormon GnRH-a

Table 1. Number of the ovulated egg and hatching rate of Asian redtail catfish (Hemibagrus nemurus) in using different doses of GnRH-a

\begin{tabular}{|c|c|c|c|}
\hline \multirow{2}{*}{ Parameter (Parameters) } & \multicolumn{3}{|c|}{ Dosis hormon (Doses of hormone) (mL/kg) } \\
\hline & 0.3 & 0.5 & 0.7 \\
\hline Ovulasi (butir) / Ovulated (eggs) & $28,838 \pm 19,946^{a}$ & $56,575 \pm 16,819^{b}$ & $65,250 \pm 9,404^{b}$ \\
\hline Derajat pembuahan (Fertilization rate) $(\%)$ & $0.0 \pm 0.0^{a}$ & $44.4 \pm 10.4^{b}$ & $61.7 \pm 11.7^{b}$ \\
\hline Derajat penetasan (Hatching rate) $(\%)$ & $0.0 \pm 0.0^{\mathrm{a}}$ & $79.8 \pm 21.2^{c}$ & $38.4 \pm 18.5^{b}$ \\
\hline \multicolumn{4}{|c|}{$\begin{array}{c}\text { Keterangan: Perbedaan huruf yang dicetak superskrip pada baris yang sama mengindikasikan adanya } \\
\text { perbedaan yang signifikan antar perlakuan }(P<0,05)\end{array}$} \\
\hline \multicolumn{4}{|c|}{$\begin{array}{l}\text { Description: Different superscript letters in the same row indicate significant difference between treatments } \\
(P<0.05)\end{array}$} \\
\hline
\end{tabular}


sebelumnya (Sahoo et al., 2005; Subagja et al., 2007; Sahoo et al., 2008; Yadav et al., 2011; DiM aggio et al., 2014; Dewantoro et al., 2017). Berdasarkan informasi jumlah telur yang berhasil ovulasi, derajat pembuahan, dan derajat penetasan pada penelitian dengan tiga dosis yang berbeda ini, hasil terbaik ditunjukkan pada dosis $0,5 \mathrm{~mL} / \mathrm{kg}$ untuk aplikasi produksi benih ikan baung. Ada perbedaan pada penelitian terdahulu (Subagja et al., 2015), di mana induk ikan baung yang digunakan adalah populasi Cirata generasi asal alam (G-0) penggunaan hormon gonadotropin analog yang menghasilkan jumlah induk ovulasi terbanyak yaitu menggunakan dosis $0,6 \mathrm{~mL} / \mathrm{kg}$ bobot induk. Hal yang sama terjadi pada hasil pemijahan ikan baung pada generasi pertama (Kristanto et al., 2016). Hasil ini menunjukkan bahwa kemungkinan dosis $0,7 \mathrm{~mL} / \mathrm{kg}$ memiliki hasil yang lebih baik atau masih dapat ditingkatkan lagi dosisnya.

Hasil pengamatan sintasan larva menunjukkan bahwa sintasan tertinggi didapatkan pada larva yang dihasilkan dari perlakuan dosis penyuntikan $0,5 \mathrm{~mL} /$ $\mathrm{kg}$ dengan nilai sintasan sebesar 78,8 $\pm 18,4 \%$ Nilai tersebut berbeda nyata dibandingkan dengan perlakuan dosis $0,7 \mathrm{~mL} / \mathrm{kg}$ yang menghasilkan sintasan larva sebesar 55,2 $\pm 5,1 \%(P<0,05)$ (Gambar 1$)$. Sementara itu, pada perlakuan dosis $0,3 \mathrm{~mL} / \mathrm{kg}$ tidak dilakukan pengamatan karena tidak ada telur yang menetas menjadi larva dari perlakuan tersebut.

Pada penelitian ini, sintasan larva yang dihasilkan dari perlakuan dosis penyuntikan $0,5 \mathrm{~mL} / \mathrm{kg}$ merupakan nilai tertinggi $(78,8 \pm 18,4 \%$. Hasil penelitian sebelumnya, nilai sintasan pada pemijahan buatan pada induk asal populasi Cirata pada generasi awal (G-0) yaitu 35,17 $\pm 21,49 \%($ Subagja et al., 2015).
Namun, nilai tersebut tidak dapat dibandingkan karena kondisi perlakuan dosis hormon yang berbeda pada masing-masing penelitian.

Respons induk ikan baung generasi kedua terhadap perlakuan hormon memperlihatkan adaptasi yang konsisten. Pada penelitian ini, penggunaan dosis hormon lebih rendah yaitu $0,5 \mathrm{~mL} / \mathrm{kg}$ menunjukkan kualitas sintasan larva ikan baung lebih baik dibandingkan dengan penelitian sebelumnya yang menggunakan ikan generasi pertama populasi Cirata dengan dosis $0,6 \mathrm{~mL} / \mathrm{kg}$; yaitu dengan nilai sintasan sebesar $63 \pm 2,4 \%$ (Kristanto et al., 2016). Oleh karena itu, hasil percobaan ini dapat digunakan untuk perbaikan adaptasi dalam domestikasi ikan baung.

Hasil pengamatan larva pada proses penetasan, diperoleh beberapa larva yang abnormal (bentuk badan bengkok), diduga ada kaitannya dengan kualitas telur dari induk yang mengakibatkan tingginya larva abnormal. Penelitian lebih lanjut diperlukan guna mengetahui lebih rinci pada proses awal perkembangan embrio. Embrio yang abnormal dapat mengakibatkan tingginya larva abnormal.

\section{KESIMPULAN}

Dosis penyuntikan hormon $\mathrm{GnRH}-\mathrm{a}$ 0,5 mL/kg pada induk ikan baung saat proses pemijahan buatan menghasilkan derajat penetasan yang lebih tinggi dibandingkan dosis 0,3 dan $0,7 \mathrm{~mL} / \mathrm{kg}$; serta sintasan larva yang lebih baik dibandingkan dosis $0,7 \mathrm{~mL} / \mathrm{kg}$. Sedangkan nilai jumlah telur yang berhasil ovulasi dan derajat pembuahan yang relatif lebih baik ditemukan pada perlakuan dosis $0,7 \mathrm{~mL} / \mathrm{kg}$ dibandingkan dengan dosis 0,3 dan $0,5 \mathrm{~mL} / \mathrm{kg}$.

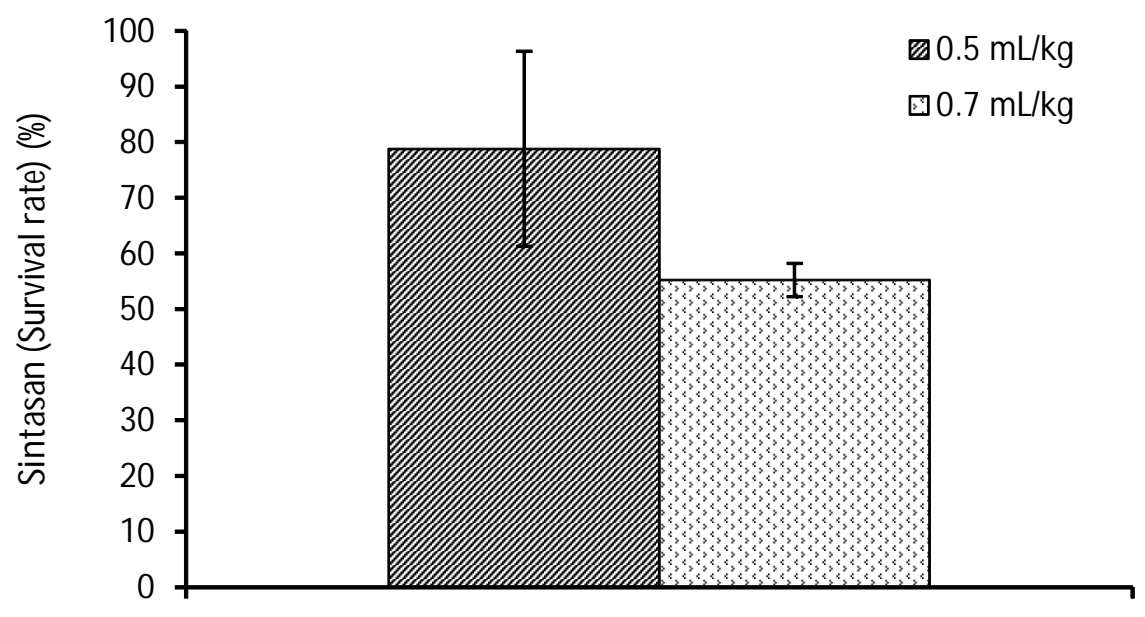

Gambar 1. Sintasan larva ikan baung (Hemibagrus nemurus) hasil dari pemijahan buatan dengan dosis penyuntikan hormon yang berbeda selama tujuh hari masa pemeliharaan.

Figure 1. Survival rate of Asian redtail catfish (Hemibagrus nemurus) larvae resulted from different doses of hormone during induced spawning with seven days of rearing period. 


\section{UCAPAN TERIMA KASIH}

Penelitian ini dibiayai oleh DIPA 2017 BRPBATPP, Bogor. Penulis mengucapkan terima kasih kepada Ir. Anang Hari Kristanto, M.Sc., Ph.D., Otong Zenal Arifin, S.Pi., M.Si., Sudarmaji, Bambang Priadi, Ujang Heri Heryana, dan Ardea Kumarasetya yang telah membantu terlaksananya penelitian ini.

\section{DAFTAR ACUAN}

Achionye-Nzeh, C.G. \& Obaroh, I.S.R.A.E.L. (2012). Ovaprim doses effects on eggs of African mudfish (Clarias gariepinus). International Journal of Life Science and Pharman Research, 2(1), 6-9.

Adebiyi, F.A., Siraj, S.S., Harmin, S.A., \& Christianus, A. (2013). Induced spawning of a river catfish (Hemibagrus nemurus Valenciennes, 1840). Pertanika Journal of Tropical Agricultural Science, 36(1), 71-78.

Bromage, N., Jones, J., Randall, C., Thrush, M., Davies, B., Springate, J., \& Barker, G. (1992). Broodstock management, fecundity, egg quality and the timing of egg production in the rainbow trout (Oncorhynchus mykiss). Aquaculture, 100(1-3), 141-166.

Dewantoro, E., Yudhiswara, R., \& Farida. (2017). Pengaruh penyuntikan hormon ovaprim terhadap kinerja pemijahan ikan tengadak (Barbonymus schwanenfeldii). Jurnal Ruaya: Jurnal Penelitian dan Kajian IImu Perikanan dan Kelautan, 5(2), 1-9.

DiMaggio, M.A., Broach, J.S., \& Ohs, C.L. (2013). Evaluation of ovaprim and human chorionic gonadotropin doses on spawning induction and egg and larval quality of pinfish (Lagodon rhomboides). Aquaculture, 414, 9-18.

DiMaggio, M.A., Broach, J.S., \& Ohs, C.L. (2014). Evaluation of ovaprim and human chorionic gonadotropin doses on spawning induction and egg and larval quality of Pigfish (Orthopristis chrysoptera). Journal of the World Aquaculture Society, 45(3), 243257.

Gaffar, A.K. \& Muflikah, N. (1992). Penelitian budi daya ikan baung. Prosiding Hasil Penelitian Perikanan Air Tawar 1991/1992. Balai Penelitian Perikanan Air Tawar. Bogor.

Hardjamulia, A. \& Suhenda, N. (2000). Evaluasi sifat reproduksi dan sifat gelondongan generasi pertama empat strain ikan baung (M ystus nemurus) di keramba jaring apung. Jurnal Penelitian Perikanan Indonesia, 6(3-4), 24-35.

Irwanda, F. (2018). Jelang puasa, harga ikan air tawar stabil. Lampost.co., 12 Mei 2018. Retrieved from http://www.lampost.co/berita-jelang-puasa-hargaikan-air-tawar-stabil.
Kesuma, D.P. (2018). Deretan fakta ikan baung yang jadi ikan khas Sungai Cisadane. Tribun Jakarta, 5 Februari 2018. Retrieved from http:// jakarta.tribunnews.com/2018/02/05/deretan-faktaikan-baung-yang-jadi-ikan-khas-sungai-cisadane.

Kristanto, A.H., Subagja, J., Ath-thar, M.H.F., Arifin, O.Z., Prakoso, V.A., \& Cahyanti, W. (2016). Pengaruh suhu inkubasi induk dan pemberian naungan pada larva terhadap produksi benih ikan baung. Jakarta: Prosiding Forum Inovasi Teknologi Akuakultur 2016, hlm. 166-167.

Lam, T.J. (1995). Induced spawning in fish. Proceedings for workshop held in Tungkang M arine Laboratory. Taiwan. April, 22-24, 1995. Reproduction in Culture of Milkfish. p. 14-65.

Legendre, M., Slembrouck, J., Subagja, J., \& Kristanto, A.H. (2000). Ovulation rate, latency period and ova viability after GnRH-or hCG-induced breeding in the Asian catfish (Pangasius hypophthalmus; Siluriformes, Pangasiidae). Aquatic Living Resources, 13(3), 145-151.

Mylonas, C.C., Hinshaw, J.M., \& Sullivan, C.V. (1992). GnRHa-induced ovulation of brown trout (Salmo trutta) and its effects on egg quality. Aquaculture, 106(3-4), 379-392.

Nasution, Z., Utomo, A.D., Dadiek, P., \& Yusuf, S. (1993). Kajian ekonomi pada sumberdaya perikanan baung di DAS Batanghari Provinsi Jambi. Prosiding Seminar Hasil Penelitian Perikanan Air Tawar.

Nuraini, Alawi, H., Nurasiah, \& Aryani, N. (2013). Pengaruh sGnRH+ domperidone dengan dosis yang berbeda terhadap pembuahan dan penetasan telur ikan selais (Ompok rhadinurus $\mathrm{Ng}$ ). Jurnal Terubuk, 41(2), 1-8.

Olumuji, O.K. \& Mustapha, M.K. (2012). Induced breeding of African mud catfish (Clarias gariepinus Burchell 1822), using different doses of normal saline diluted ovaprim. Journal of Aquaculture Research and Development, 3(4), 1-4.

Sahoo, S.K., Giri, S.S., \& Sahu, A.K. (2005). Induced spawning of Asian catfish (Clarias batrachus Linn.): Effect of various latency periods and SGnRH-a and domperidone doses on spawning performance and egg quality. Aquaculture Research, 36(13), 1273-1278.

Sahoo, S.K., Giri, S.S., Chandra, S., \& Sahu, A.K. (2007). Effect of ovaprim doses and latency periods on induced spawning of Clarias batrachus: observation on larval deformity. Indian Journal of Experimental Biology, 45(10), 920-922.

Sahoo, S.K., Giri, S.S., \& Chandra, S. (2008). Induced spawning of Clarias batrachus (Linn): Effect of 
ovaprim doses and latency periods on the weight of stripped eggs and ovary. Asian Fisheries Science, 21, 333-338.

Slembrouck, J., Komarudin, 0., Maskur, \& Legendre, M. (2005). Petunjuk teknis pembenihan ikan patin Indonesia, Pangasius djambal. Penerbit: IRD, BRPBAT, PRPB, BRKP, $143 \mathrm{hlm}$.

Subagja, J., Sularto, \& Slembrouck, J. (2007). MiltEgg ratio in artificial fertilization of Pangasiid catfish injected by gonadotropin releasing hormoneanalog (GnRH-a) and domperidone mixture. Jurnal Akuakultur Indonesia, 2(2), 55-59.
Subagja, J., Cahyanti, W., Nafiqoh, N., \& Arifin, O.Z. (2015). Keragaan bioreproduksi dan pertumbuhan tiga populasi ikan baung (Hemibagrus nemurus Val. 1840). Jurnal Riset Akuakultur, 10(1), 25-32.

Sukendi. (2001). Biologi reproduksi dan pengendaliannya dalam upaya pembenihan ikan baung (Mystus nemurus CV) dari perairan Sungai Kampar Riau. Institut Pertanian Bogor, Bogor.

Yadav, A.K., Mishra, R.K., Singh, S.K., Varshney, P.K., Pandey, A.K., \& Lakra, W.S. (2011). Induced spawning of Asian catfish (Clarias batrachus) with different doses of $\mathrm{sGnRH}$-based drugs. Journal of Experimental Zoology, India, 14(1), 199-202. 